\title{
Research on College Sports Teaching Development under the Perspective of Sino-Russian Cooperation in Running Schools
}

\author{
Changzhu Li \\ School of physical education \\ Heihe University \\ Heihe, Heilongjiang, China 164300
}

\begin{abstract}
With the modernization of education, the internationalization level of colleges of our country in running schools improves unceasingly. The Sino-Russian cooperation in running schools develops rapidly, contributing to the introduction of high quality educational resources of Russia and the reform and development of sports education of our country as well as the formation of diversified and balanced international school-running pattern in our country. In order to improve the quality of Sino-Russian cooperation in running schools and promote the development of sports education in our country, we should transfer the idea of sports education and use scientific pattern of sports education, lay language foundation and grasp the market demands meanwhile innovate in training patterns, value process assessment and physical and mental health.
\end{abstract}

Keywords-Sino-Russian cooperation in running schools; college sports; teaching development

\section{INTRODUCTION}

At present, China and Russia have built the comprehensive strategic partnership and kept benign relationship. The benign political relationship promotes the exchange and cooperation of cultural education between China and Russia. Universities with Sino-Russian cooperation develop. Furthermore, Russian universities begin to enroll overseas students because of funding difficulties. The educational exchange of China and Russia is promoted.

\section{CURRENT SituATION OF SPORTS TEACHING IN} UNIVERSITIES WITH SINO-FOREIGN COOPERATIVE EDUCATION

\section{A. Current Situation of Sports Motivation}

Sports motivation is a crucial factor influencing sports teaching and students' learning. It is the drive of students in learning. Generally speaking, most students know the general functions of sports but know little about the special value orientation of sports. Male students have lower level than female students. The motivation of some students is to finish school. In general, the motivation of students in sports learning is positive. Small number of students holds negative attitudes. Teachers should conform to the situation and use independent

This paper is the phased research results of excellent young science and technology talents funding project of Heihe University. and open teaching pattern as well as provide more opportunities for them to learn independently. Meanwhile, teachers should guide students with weak learning motivation and take measures to stimulate their learning motivation.

\section{B. Current Situation of Interests in Sports}

Although female and male students have different interests in sports, they like sports on the whole. Male students prefer competitive sports while female students prefer recreational sports without direct body contact. The common point is that they like overseas sports activities like tae kwon do and boxing. It is because students know sports activities are conducive to them but they worship things foreign and fawn on foreign countries. Therefore, teachers need to consider the differences of interests of female and male students and properly bring in some overseas sports activities popular among students.

\section{Current Situation of Sports Teaching}

Most gym teachers in universities with Sino-Russian cooperation have bachelor degree. Few have graduate degree and title of a senior professional post. Teachers are young. As for their foreign language level, teachers graduating from key universities fail to pass the College English Test Band 4. Most teachers grasp more than four experienced professional skills. Gym teachers have enthusiasm in scientific research but the research level is low. Besides, there are more part-time gym teachers than full-time ones. Some teachers are extroverted and positive and get along well with students but have inadequate teaching experience. Teachers' researches involve more domestic sports instead of foreign ones. The foreign language level influences the ability of gym teachers to participate in international scientific research project and has adverse impact on bilingual education.

\section{Current Situation of Sports Teaching Environment}

The sports education environment in universities needs to improve. Sports equipment and sports ground of many universities only just meet teaching requirements. A very few schools even fail to provide enough ground and equipment for teaching. The reasons are as follow: The national investment is inadequate; partner institutions expand blindly; the number of new student increases continuously but the campus 
construction is backward; the number of gym teachers is insufficient.

\section{NECESSITY OF SINO-RUSSIAN COOPERATION IN RUNNING SCHOOLS}

China and Russia are neighboring countries, the important countries in Northeast Asia and the permanent members of the Security Council, having many common interests. In the twenty-first century, China and Russia have benign development and continuously strengthen cooperation. People in the two countries should understand mutually and learn from others' strong points to offset their weakness in order to develop and advance together. Therefore, the Sino-Russian cooperation in running schools is necessary.

\section{A. The Sino-Russian Cooperation in Running Schools Makes for the Introduction of High Quality Russian Educational Resources and Promotes the Reform and Development of Sports Education in Our Country}

Our country pays more attention to education and the educational investment increases continuously. It contributes to the rapid development of higher education. Because of the low starting point, universities of our country fall behind that of developed countries in course design, teachers' level and the development of teaching materials, and lack scientific and technological innovation. The cooperation with Russia in running schools can bring in new teaching methods and course structure, update our knowledge structure, optimize teaching body and strengthen the communication and cooperation of teachers between the two countries. We can invite teachers, experts and scholars of Russia to carry out scientific research and teaching. Meanwhile, we can send Chinese teachers to Russia and learn their scientific knowledge, scientific research skills and experience. It avails Chinese teachers to learn Russian teaching and scientific research skills and technology and narrows the gap between our country and the world's advanced educational level. Under the pattern of Sino-Russian cooperation in running schools, China and Russia can jointly train talents at all levels, build interdiscipline and new-rising subjects and research international projects together to serve economic and social development.

\section{B. The Sino-Russian Cooperation in Running Schools Contributes to the Formation of Diversified and Balanced International School-Running Pattern}

Most universities in Sino-foreign cooperative education are from Europe and America. China is at a disadvantage in school-running negotiation. If the Sino-Russian cooperation in running schools has benign development, we can less depend on Europe and America, increase the bargain chips with cooperative countries and reduce the cost in cooperation in running schools. The higher education level of Russia takes the international leading position. Russia has many international famous universities, regarded as a great power of science and education. Russia has abundant scientific research foundation, first-class educational level and the world's top technology. The scientific research in some fields cannot be ignored. Compared with developed countries, the tuition fee of Russian universities is lower within the tolerance range of Chinese families. The diploma of Russian universities is recognized by Europe and America. The Sino-Russian cooperation in running schools can save the cost and improve the quality in school running of our country. Provinces in East China can cooperate with Europe and University in running schools. Provinces in the Midwest should cooperate with Russia in running schools. It avails to form scientific and reasonable pattern of international cooperation in running schools.

\section{RESEARCH ON THE DEVELOPMENT OF SPORTS \\ TEACHING UNDER THE PERSPECTIVE OF SINO-RUSSIAN COOPERATION IN RUNNING SCHOOL}

\section{A. Change the Concept of Sports Education}

The Guidance Outline of Sports Teaching in Universities of our country stipulates the objective of physical education to promote good health and sports quality. Therefore, universities should carry out sports education through the concept of healthy sports. The sports concept in joint universities is advanced and meets students' demands in invigorating health effectively and promotes the sports quality of Chinese and Russian students.

The health pursued by healthy sports includes physical and mental health as well as the training of social adaptation ability.

In sports teaching, universities pay attention to the improvement of students' physical quality. Meanwhile, they should improve students' mental health and social adaptation ability. The objective of sports reform is to comprehensively strengthen students' sports ability. Schools need to improve students' sports skills and train their emotional adjustment and cognitive competence. The emotional adjustment of students is to adjust unhealthy emotions and form cooperative awareness and group consciousness in sports activities. Students' cognitive competence includes the cognition of traditional sports hygiene, rehabilitation and health care as well as sports appreciation and evaluation.

\section{B. Use Scientific Sports Teaching Pattern}

The traditional sports teaching pattern of our country faces new problems in the Sino-Russian cooperation in running schools. New teaching patterns must be adopted. Three new appropriate sports teaching patterns are involved, including teaching method of Sino-Russian cooperation, teaching method of making Russian resources serve China and disperse teaching method.

1) Teaching method of Sino-Russian combination: We refer to the merits of Russian teaching methods and reserve the quintessence of traditional Chinese teaching methods to integrate. Universities of China and Russia can negotiate, change the traditional teaching methods, reset teaching concept and improve teaching methods, optimize course arrangement. It is scientific because it conforms to the reality of sports teaching in China and absorbs the merits of sports teaching of Russia.

2) Teaching method of making Russian resources serve China: It means using teaching methods of Russia. We introduce sports course and teaching materials, educational 
concept, teaching means and methods, gym teachers of Russia to China. It enables students to receive good education from other countries at home and saves students' cost in attending schools. The teachers introduced can improve sports teaching and inject new vitality to the sports reform.

3) Loose teaching method: It is realized by mutual dispatch of teachers, referring to a teaching method and communication means. Specifically speaking, Chinese universities send teachers to Russia to teach and invite Russian teachers to teach in China. Besides, it can implement through further education. Chinese gym teachers can learn and receive training in Russia, absorb merits and experience of Russian teaching methods and apply it to domestic teaching. The disperse teaching includes not only the mutual dispatch of teachers but also the mutual dispatch and exchange of students. Domestic universities can send exchange students to learn and practice in Russia to experience the teaching.

\section{Lay Solid Language Foundation}

China and Russia signed the medium and long term cooperation plan between northeast China and Russian FarEast and Siberia in 2009. The signature of this cooperation agreement brings new opportunities for Sino-Russian cooperation and educational exchange. Chinese universities invite Russian gym teachers. But linguistic differences exist because Russian teachers speak Russian and Chinese students speak China. Therefore, in the future, universities must help students to lay solid language foundation through learning some basic Russian and ask Russian teachers to learn some Chinese.

\section{Accurately Grasp Market Demands}

Gym teachers should accurately grasp the market demands instead of teaching blindly to make graduates have competitiveness. It concerns the vocational development of graduates and the long-run development of Sino-Russian cooperation in running schools.

\section{E. Innovate in Training Pattern}

At present, the Sino-Russian cooperation in running schools uses Two plus Two training pattern. Students spend two years in China and two years in Russia to finish school. It has drawbacks and needs reform and innovation. We can adopt One plus Three training pattern for sports majors. They spend one years in China to learn Russian and professional knowledge and three years in professional learning in Russia. Students with weak Russian can spend one year in learning preparatory course on this basis.

\section{F. Value Process Assessment and Physical and Mental Health}

Sports education of our country should value students' allround development. Universities of Sino-Russian cooperation should value the process of students' advancement and learning in sports evaluation. Meanwhile, they should arouse students' enthusiasm in taking exercise and improve their physical and mental health.

\section{CONCLUSION}

To sum up, the Sino-Russian cooperation in running schools makes for the introduction of high quality educational resources of Russia and the reform and development of sports education as well as the formation of diversified and balanced international school-running pattern in our country. In order to improve the quality of Sino-Russian cooperation in running schools and promote the development of sports education in our country, we should transfer the idea of sports education and use scientific pattern of sports education, lay language foundation and grasp the market demands meanwhile innovate in training patterns, value process assessment and physical and mental health.

\section{REFERENCES}

[1] Li Changzhu, Zhao Weiming. Discussion on the Teaching Value of Introducing Skiing in College Sports [J], Science and Technology of Stationery and Sporting Goods, 2012(04)

[2] Liu Qi, Wu Tienan. Comparative Research on Professional Course Provision of Sports Education in China and Russia [J], Journal of Heihe Univeristy, 2010(03)

[3] Song Liquan. Current Situation and Thinking on Sino-Russian Cooperation in Running Schools in Northern Xinjiang [J], China Higher Education Research, 2010(02)

[4] Liu Qiao. Discussion on Significance and Development Pattern of SinoRussian Cooperation in Running Schools [J], Journal of Suihua University, 2009(04)

[5] Guo Jianwei. Research on Major Problems and Countermeasures of Sino-Russian Cooperation in Running Schools [D], Northeast Normal University, 2011. 